\title{
EFEKTIVITAS LOW POWER LASER TERAPI DAN PROPRIOCEPTIF NEUROMUSCULAR FACILITATION PADA ULKUS DIABETIKUM DERAJAT 2
}

\author{
Made Hendra Satria Nugraha ${ }^{1}$, Nila Wahyuni ${ }^{2}$, Putu Ayu Sita Saraswati ${ }^{3}$ \\ ${ }^{1,3}$ Departemen Fisioterapi, Fakultas Kedokteran, Universitas Udayana \\ ${ }^{2}$ Departemen Faal, Fakultas Kedokteran, Universitas Udayana \\ Email: hendra_satria@unud.ac.id
}

\begin{abstract}
ABSTRAK
Ulkus diabetikum merupakan salah satu komplikasi diabetes yang paling memberatkan penderita diabetes melitus. Apabila dikaji melalui pendekatan International Classification of Function (ICF) terdapat beberapa permasalahan yang berkaitan dengan ulkus diabetikum, di antaranya: adanya nyeri, keterbatasan gerak, luka terbuka, hilangnya sensasi sensoris ataupun kemampuan motorik. Berbagai macam modalitas dapat digunakan untuk membantu mengatasi permasalahan tersebut, yaitu dengan menggunakan laser dan pendekatan terapi latihan seperti aplikasi proprioceptive neuromuscular facilitation (PNF). Metode penelitian pada study ini adalah narrative review berupa kajian beberapa jurnal penelitian yang berhubungan dengan efektivitas low power laser therapy dan proprioceptive neuromuscular fascilitation pada penderita ulkus diabetikum. Efek primer pada sel terhadap penggunaan laser yaitu terjadinya peningkatan metabolisme oksidatif untuk menghasilkan lebih banyak ATP yang akhirnya mengarah pada normalisasi fungsi sel, penghilang nyeri, dan penyembuhan luka. PNF merupakan metode peningkatan gerakan dan fasilitasi neuromuscular untuk memfasilitasi kontraksi otot. Metode ini memiliki tujuan utama mencapai kebutuhan individu, dan dengan demikian dapat melakukan gerakan fungsional, melalui fasilitasi, penghambatan (inhibisi), penguatan, serta relaksasi kelompok otot. Berdasarkan kajian pustaka tersebut, maka dapat disimpulkan bahwa: (1) Low power laser therapy efektif dalam memperbaiki luka pada penderita ulkus diabetikum grade 2, (2) Proprioceptif Neuromuscular Facilitation (PNF) efektif dalam meningkatkan konduksi saraf sensoris dan motoris yang berkaitan pada pergerakan ankle pada ulkus diabetikum grade 2, dan (3) Kombinasi low power laser therapy dan Proprioceptif Neuromuscular Facilitation efektif dalam memperbaiki keterbatasan gerak dan fungsi ulkus diabetikum grade 2.
\end{abstract}

Kata kunci: low power laser therapy, proprioceptif neuromuscular facilitation, ulkus diabetikum

\section{THE EFFECTIVENESS OF LOW POWER LASER THERAPY AND PROPRIOCEPTIVE NEUROMUSCULAR FACILITATION ON GRADE 2 DIABETIC FOOT ULCERS}

\begin{abstract}
Diabetic ulcers are one of the most severe complications of diabetes in people with diabetes mellitus. When examined through the International Classification of Function (ICF) approach, there are several problems associated with diabetic ulcers, including: the presence of pain, limited movement, open wounds, loss of sensory sensation or motor ability. There are some modalities can be used to help these problems, namely by using laser and therapeutic approaches
\end{abstract}


such as the application of proprioceptive neuromuscular facilitation (PNF). The method of this paper is an article review by using secondary data taken from research journals which are related to the effectiveness of the use of low power laser therapy and proprioceptive neuromuscular facilitation in diabetic ulcer patients. The primary effect of laser usage on cell is increasing oxidative metabolism to produce more ATP, which ultimately leads to the normalization of cell function, pain relief, and wound healing. PNF is a method of enhancing neuromuscular movement and facilitation to facilitate muscle contraction. This method has the primary goal of achieving individual needs, and thus can perform functional movements, through facilitation, inhibition, strengthening and relaxation of muscle groups. Based on the literature review, it can be concluded that: (1) Low power laser therapy is effective in repairing wounds in patients with grade 2 diabetic ulcers, (2) Proprioceptive Neuromuscular Facilitation (PNF) is effective in improving sensory and motor neuronal conduction associated with ankle movement in grade 2 diabetic ulcers, and (3) The combination of low power laser therapy and Proprioceptive Neuromuscular Facilitation is effective in improving the limitations of motion and function of grade 2 diabetic ulcers.

\section{Keywords: low power laser therapy, proprioceptive neuromuscular facilitation, diabetic ulcer}

\section{PENDAHULUAN}

American Diabetes Association menyatakan bahwa diabetes melitus sebagai suatu kelompok penyakit metabolik dengan karakteristik hiperglikemia yang terjadi karena kelainan sekresi insulin, kerja insulin atau keduanya. Diabetes Melitus diklasifikasikan menjadi DM tipe 1 (insulindependent) dimana pankreas gagal menghasilkan insulin ditandai dengan kurangnya produksi insulin, sedangkan DM tipe 2 (non insulin dependent0 disebabkan karena ketidakmampuan tubuh menggunakan insulin secara efektif yang dihasilkan oleh pankreas. ${ }^{1,2}$

Ulkus diabetikum merupakan salah satu komplikasi diabetes yang paling memberatkan penderita diabetes melitus. Ulkus yang tidak kunjung sembuh disebabkan karena adanya neuropati dan vaskulopati di jaringan perifer. Berdasarkan WHO dan International Working Group on the Diabetic Foot, kaki diabetes adalah keadaan adanya ulkus, infeksi, dan atau kerusakan dari jaringan, yang berhubungan dengan kelainan neurologi dan penyakit pembuluh darah perifer pada ekstremitas bawah. Gangguan pada aliran darah dan saraf ini dikarenakan hiperglikemia yang tidak terkontrol. Prevalensi kaki diabetes di Amerika Serikat diperkirakan sebesar $4 \%$. Diperkirakan sebesar 5\% pasien dengan diabetes pernah menderita kaki diabetes, dengan lifetime risk sebesar 15\%. Sebanyak
60-80\% ulkus yang timbul dapat disembuhkan, sedangkan sebesar 10-15\% tidak sembuh dan sisanya sebesar 5-24\% berakhir pada amputasi dalam kurun waktu 6 -18 bulan. ${ }^{1,3,4}$

Terdapat 3 macam jenis ulkus diabetes, yaitu ulkus neuropati, ulkus iskemia dan ulkus neuroiskemia (campuran). Karakteristik ulkus neuropati adalah bulat, dikelilingi oleh kalus, tidak nyeri dan berlokasi di atas tulang-tulang yang menonjol pada jari-jari kaki atau di daerah plantar. Ulkus iskemia biasanya pucat, nekrosis, sangat sakit, tidak terbentuk kalus dan lokasinya sering pada jari-jari kaki, tepi-tepi kaki, dan tumit. Luka yang disebabkan oleh neuropati akan lebih mudah sembuh dibandingkan luka karena neuroiiskemia. Diperkirakan bahwa sekitar 40-70\% amputasi non-trauma dikerjakan pada pasien dengan diabetes. ${ }^{1,3,4}$

Sistem klasifikasi ulkus didasarkan pada beberapa parameter yaitu luasnya infeksi, iskemia, neuropati, lokasi, kedalaman, serta luasnya luka. Sistem klasifikasi yang paling umum dipergunakan adalah sistem klasifikasi wagner. Sistem Klasifikasi Ulkus Wagner-Meggit merupakan klasifikasi yang berdasar pada kedalaman luka yang terdiri dari 6 grade luka. Derajat 0 (Kulit masih utuh, ada kelainan bentuk kaki akibat neuropati), derajat 1 (Ulkus superfisial terlokalisir), derajat 2 (Ulkus lebih dalam, mengenai tendon, ligament, otot, sendi, 
belum mengenai tulang, tanpa selulitis atau abses), derajat 3 (Abses yang dalam dengan atau tanpa osteomyelitis), derajat 4 (Gangren jari atau kaki bagian distal), dan derajat 5 (Gangren seluruh kaki)., 1,3,5

Perubahan struktural pada anatomi kaki dan persendian menyebabkan kelemahan dan musclewasting pada otot-otot intrinsik kecil. Hal ini menyebabkan hilangnya keseimbangan saat berjalan, clawing of toes, serta plantar fleksi metatarsal head (charcot foot). Musculus interosseous dan otot-otot intrinsik berfungsi sebagai penyeimbang dan menahan phalang agar ekstensi. Gangguan morfologi dan fungsional struktur kaki, jari kaki, dan sendi akanmempengaruhi absorbsi dan distribusi tekanan saat berjalan.Efek pada kaki meliputi reduksi gerakan dan perubahan terhadap sudut subtalar dan sendi metatarsophalangeal pertama.Pada pasien diabetes, tendon fleksor dan ekstensor cenderung lurus dan kaku. Deformitas equinus dapat terjadi akibat pemendekan tendon Achilles dan kolaps fascia plantaris. Hal ini menyebabkan terjadinya hammer toes dan tekanan beban tubuh terpusat pada permukaan anterior jarijari kaki. Charcot foot merupakan deformitas ulkus diabetes akibat neuropati yang klasik dengan empat tahap perkembangan., ${ }^{1,5}$ Apabila dikaji melalui pendekatan ICF (International Classification of Function) terdapat beberapa permasalahan yang berkaitan dengan ulkus diabetikum, di antaranya: adanya nyeri, keterbatasan gerak, luka terbuka, hilangnya sensasi sensoris ataupun kemampuan motorik. Berbagai macam modalitas dapat digunakan untuk membantu mengatasi permasalahan tersebut, yaitu dengan menggunakan laser dan pendekatan terapi latihan seperti aplikasi PNF.

\section{METODE}

Metode penelitian pada study ini adalah narrative review berupa kajian beberapa jurnal penelitian yang berhubungan dengan efektivitas low power laser therapy dan proprioceptive neuromuscular fascilitation pada penderita ulkus diabetikum.

\section{PEMBAHASAN \\ Kombinasi Low Power Laser Therapy dan Proprioceptive Neuromuscular Facilitation dalam Tatalaksana Penanganan Ulkus Diabetikum}

Laser merupakan aplikasi klinis penggunaan energi elektromagnetik yang memiliki panjang gelombang $100-10.000$ nanometer $\left(10^{-9}\right)$. Energi cahaya ditransmisikan melalui ruang sebagai suatu gelombang yang memiliki kumpulan energi yang disebut sebagai photons. Laser dapat diklasifikasikan berdasarkan intensitas energi yang dihantarkan, yaitu: low-power laser (cold laser) dan high-power laser (hot laser). High-power laser digunakan dalam prosedur operasi, bidang opthalmogi, onkologi, dan dermatologi. Sementara low-power laser dikenal sebagai "cold" laser dan biasa digunakan untuk proses perbaikan jaringan (wound healing) dan mengatasi nyeri. Lowpower laser akan lebih menyebabkan efek fotokimia daripada thermal. Laser yang biasa digunakan dalam manajemen konservatif kondisi medis meliputi: Helium Neon (HeNe) yang termasuk ke dalam gas laser dan Gallium Arsenide (Ga As) yang tergolong ke diode laser (semikonduktor). ${ }^{6}$

Sinar laser memiliki sifat unik monokromatisitas (panjang gelombang tunggal), collimation (perjalanan dalam satu arah tanpa divergensi) dan koherensi (semua gelombang menyatu dalam fase). ${ }^{7}$ Sifat-sifat ini memungkinkan sinar laser menembus permukaan kulit secara non-invasif. Laser terapeutik bersifat athermic atau tanpa transfer panas yang cukup $\left(<0,65^{\circ} \mathrm{C}\right)$ sehingga energi foton dapat ditransfer secara langsung ke sel target dan kerusakan termal dapat dihindari. 7,8 Laser terapeutik menggunakan cahaya monokromatik dalam kisaran 630 hingga 905 nm. ${ }^{9}$ Efek primer pada sel terhadap penggunaan laser yaitu foton yang dipancarkan oleh laser mencapai mitokondria dan membran sel dari sel 
fibroblas, keratinosit atau endotel di mana energi fotonik diserap oleh chromophores (sitokrom mitokondria, porfirin dan flavoprotein) dan diubah menjadi energi kinetik kimia di dalam sel. ${ }^{7}$ Hal ini menyebabkan perubahan permeabilitas membran, meningkatkan sinyal antara mitokondria, nukleus dan sitosol, dan peningkatan metabolisme oksidatif untuk menghasilkan lebih banyak ATP yang akhirnya mengarah pada normalisasi fungsi sel, penghilang nyeri, dan penyembuhan luka. ${ }^{10,11,12,13}$ Penggunaan laser akan membantu peningkatan metabolisme oksidatif sebagai hasil akhirnya yaitu peningkatan produksi ATP. Dengan peningkatan produksi ATP ini akan membantu meningkatkan sinyal antar sel yang berujung pada peningkatan growth factors dan pelepasan sitokin. Hal ini mengaktivasi makrofag dan peningkatan jumlah sel mast yang berperan dalam mengeliminasi sel dan matriks yang rusak pada tahap inflamasi. Selain itu, terjadi pula peningkatan sintesis prokolagen yang berperan dalam perbaikan jaringan. 6,14

Efek sekunder dapat menyebabkan amplifikasi fotoreaksi primer dimana efek metabolik menghasilkan berbagai perubahan fisiologis pada tingkat sel, seperti perubahan permeabilitas membran sel. ${ }^{12,13,15}$ Kalsium dilepaskan dari mitokondria ke sitoplasma yang merubah level kalsium intraseluler yang menstimulasi metabolisme sel dan pengaturan jalur sinyal yang bertanggung jawab untuk keadaan yang diperlukan saat perbaikan luka seperti migrasi sel, sintesis DNA dan RNA, mitosis sel, sekresi protein dan proliferasi sel. Efek tersier didapatkan secara tidak langsung dimana sel yang diiradiasi atau diberi energi berkomunikasi satu sama lain, serta terjadi pada sel yang tidak disinari, melalui peningkatan kadar sitokin atau faktor pertumbuhan menghasilkan komunikasi antar-sel. Peningkatan sintesis endorfin dan penurunan bradikinin menghasilkan penghilang rasa sakit. Studi telah mencocokkan spektrum tindakan untuk biostimulasi dengan spektrum absorpsi sitokrom c oksidase dan telah menemukan kesamaan di daerah spektrum merah dan dekat inframerah (IR) (panjang gelombang antara 6328 A - 9100 A). Semua keadaan oksidasi individu dari enzim cytochrome c oxidase memiliki spektrum absorpsi yang berbeda, sehingga dapat diperhitungkan pula perbedaan dalam spektrum aksi Low Laser Therapy. Rentang panjang gelombang yang penting untuk fototerapi $(600-860 \mathrm{~nm})$ memiliki empat wilayah aktif, tetapi posisi puncak tidak persis sama untuk semua spektrum aksi. Posisi puncak adalah antara 613,5 dan 623,5 nm (dalam satu spektrum, pada $606 \mathrm{~nm}$ ) di maksimum merah. Sinar far-red maximum memiliki posisi puncak yang tepat antara 667,5 dan $683,7 \mathrm{~nm}$ sementara near-infrared maximum memiliki posisi puncak di kisaran 750,7-772,3 nm dan 812,5 - 846,0 nm. ${ }^{10,14}$

Polineuropati sensorimotor diabetik atau diabetic sensorimotor polyneuropathy (DSP) merupakan komplikasi mikrovaskular yang paling umum terjadi pada diabetes tipe I dan II, dan menimbulkan tantangan manajemen dalam pencegahan komplikasi pada kaki. Manajemen DSP dipusatkan pada kontrol glikemik yang optimal, perawatan kaki yang rajin, dan kontrol nyeri sebagai cara mencegah perkembangan DSP dan mengurangi morbiditas yang terkait dengan komplikasi kaki. ${ }^{18,19}$ Penelitian Tantawy dan Zakaria pada tahun 2010 tentang efektivitas peran fisioterapi dalam manajemen diabetic neuropathy foot ulcers mendapatkan hasil yang signifikan dalam hal perbaikan jaringan yang mengalami ulkus serta fungsi sensoris dan motoris dari saraf common peroneal dan posterior tibial nerve. Penelitian tersebut menggunakan 2 kelompok perlakuan, dimana pada kelompok kontrol merupakan pasien diabetes mellitus tipe 2 dan termasuk ke dalam grade II diabetic foot ulcers diberikan terapi medis konservatif. Pada kelompok intervensi, selain penerapan terapi medis, juga diaplikasikan pemberian laser terapi 
pada area ulkus serta latihan proprioceptive neuromuscular stabilization. ${ }^{18}$

Penelitian dari (Tantawy dan Zakaria, 2010) menunjukkan bahwa terapi laser intensitas rendah membantu dalam penyembuhan ulkus kaki dan secara signifikan mengurangi ukuran ulkus. Hal ini dikaitkan dengan kemampuan laser untuk meningkatkan pelepasan faktor pertumbuhan dari fibroblas dan merangsang proliferasi sel, dan meningkatkan konversi fibroblas menjadi myofibroblast. ${ }^{18,20}$ Selain itu iradiasi laser menghasilkan efek sterilisasi dari bakteri yang menginfeksi ulkus diabetik, dan penurunan dalam ukuran ulkus. ${ }^{18,21}$ Laser juga membantu dalam hal pelepasan faktor pertumbuhan dan sitokin dari monosit yang menginduksi proliferasi sel dan perbaikan jaringan. $^{22}$ Evaluasi histologis pada tikus diabetes menunjukkan bahwa iradiasi laser meningkatkan epitelisasi luka, pembentukan jaringan granular, dan pengendapan kolagen. ${ }^{18,23,24}$ Hal ini ditunjukkan ketika iradiasi laser menstimulasi proliferasi sel fibroblast, memediasi perubahan limfosit dan proses imunitas, yang memiliki peran dalam persistensi luka kronis, dan efek ini dapat menyebabkan percepatan penyembuhan. ${ }^{22}$

Rachkind dkk. melaporkan bahwa, laser secara signifikan meningkatkan aktivitas listrik dari saraf yang terganggu atau mengalami lesi. Tantawy dan Zakaria, 2010 juga menyatakan bahwa terdapat peningkatan signifikan konduksi saraf setelah terapi laser. ${ }^{18,25}$ Gejala-gejala neuropati sensorimotor meliputi: kelemahan otot (bukan kelelahan), atrofi, masalah keseimbangan, ataxic gait dan gejala-gejala sensorik (nyeri, parestesia, mati rasa dan kelumpuhan, dan kram). ${ }^{26}$ Untuk mengatasi permasalahan tersebut, maka dapat dipalikasikan pemberian Proprioceptive Neuromuscular Facilitation. PNF atau (Proprioceptive Neuromuscular Facilitation) merupakan metode peningkatan gerakan dan fasilitasi neuromuscular untuk memfasilitasi kontraksi otot. ${ }^{16,17}$ Metode ini memiliki tujuan utama mencapai kebutuhan individu, dan dengan demikian dapat melakukan gerakan fungsional, melalui fasilitasi, penghambatan (inhibisi), penguatan dan relaksasi kelompok otot. Selain itu, PNF mendukung sinkronisasi dan pelatihan koordinasi gerakan, meningkatkan aktivitas hidup sehari-hari, dan kualitas hidup. Teknik ini menggunakan kontraksi otot secara konsentrik, eksentrik, dan statis (isometrik) dikombinasikan dengan fasilitasi resistensi dengan pola gerakan diagonal dan aplikasi stimulus sensorik berupa pendengaran, visual, proprioceptive dan rangsangan kulit. $^{17}$ Pada neuropati diabetes, ada penurunan dalam sensitivitas taktil dan termal, terutama di tumit. Daerah ini mengandung jumlah keratin dan lemak yang lebih besar dan menerima persarafan dari sural nerve. Saraf ini adalah saraf pertama yang rusak selama perkembangan neuropati diabetik. Fungsi otot menurun, terutama pada otot kaki intrinsik, tibialis anterior, dan tricepssurae. Penurunan ini karena perubahan struktur kolagen atau juga karena kehilangan kekuatan. ${ }^{27}$ PNF yang diaplikasikan dengan menggunakan resistansi dapat membantu dalam hal memfasilitasi kontraksi otot, memaksimalkan kontrol motorik, dan membantu kesadaran gerakan, yang mengarah ke suatu peningkatan respon otot ke korteks.

Peningkatan kekuatan otot dengan menggunakan tahanan akan menyebabkan peningkatan ketegangan pada serabut otot dimana dapat menyebabkan perubahan terkait dengan kerusakan otot, merusak hubungan intrasarcomer, menghasilkan lesi mikro yang melepaskan sitokin, serta memicu mekanisme respon inflamasi pada fase akut. Produksi sitokin dan pelepasan faktor kemoatraktif bertanggung jawab untuk mensinyalkan monosit dan sel polimorfonuklear pada endotel vaskular. Selsel ini memulai proses kemotaksis, menempel ke dinding endothelium, dan masuk ke ruang antar sel-sel endotel, sampai mencapai daerah yang terluka. Faktor-faktor chemo-atraktan ini menyebabkan 
peningkatan proses penyembuhan intra muskular, sebagai akibat peningkatan jumlah protein otot dan oleh karena itu, terjadilah peningkatan kekuatan. Setelah proses ini berlangsung limbah diapedesis dari jaringan otot kemudian difagositosis dan terdegradasi oleh makrofag dan neutrofil dan dilanjutkan dengan regenerasi otot dengan melepaskan faktor penstimulasi pertumbuhan pada sel-sel satelit. Di samping proses ini, ketika ada kerusakan otot, myoglobin $(\mathrm{Mb})$, enzim creatine kinase (CK) dan laktat dehidrogenase (LDH) masuk ke dalam sirkulasi. Proses inilah yang akan menyebabkan peningkatan miofibril, dan dengan demikian dapat diperoleh hipertrofi otot dan peningkatan kekuatan otot. ${ }^{27}$

\section{SIMPULAN}

Berdasarkan kajian pustaka tersebut, maka dapat disimpulkan bahwa:

1. Low power laser therapy efektif dalam memperbaiki luka pada penderita ulkus diabetikum grade 2.

2. Proprioceptif Neuromuscular Facilitation (PNF) efektif dalam meningkatkan konduksi saraf sensoris dan motoris yang berkaitan pada pergerakan ankle pada ulkus diabetikum grade 2

3. Kombinasi low power laser therapydan Proprioceptif Neuromuscular Facilitationefektif dalam memperbaiki keterbatasan gerak dan fungsi ulkus diabetikum grade 2 .

\section{DAFTAR PUSTAKA}

1. Pertama, D. Validitas Skor Tardivo Untuk Memprediksi Terjadinya Amputasi Pada Kaki Diabetes Di Rsup Sanglah. 2016. Universitas Udayana: Denpasar
2. Muhartono dan Sari, I. Ulkus Kaki Diabetik Kanan dengan Diabetes Mellitus Tipe 2. Jurnal AgromedUnila. 2017; 4(1): 133 - 139

3. Zarkasi, M. Hubungan Antara Derajat Ulkus Diabetikum Dengan Kemampuan Activities Of Daily Living (ADL) Pada Pasien DM Tipe 2 Di RSUD Panembahan Senopati Bantul. 2016; Yogyakarta: Stikes Jenderal Achmad Yani

4. Rahmaningsih, B. Hubungan Antara Nilai Ankle Brachial Index Dengan Kejadian Diabetic Foot Ulcer Pada Penderita Diabetes Melitus Tipe 2 Di RSUD DR. Moewardi Surakarta. 2016; Surakarta:UMS

5. Yunus, B.Faktor-Faktor yang Mempengaruhi Lama Penyembuhan Luka Pada Pasien Ulkus Diabetikum Di Rumah Perawatan Etn Centre Makassartahun 2014. 2015; Makassar: FKIK UIN Alauddin Makassar

6. Prentice W, Quillen WS, Underwood F. Therapeutic Modalities for Physical Therapy $2^{\text {nd }}$ ed. United States of America. The McGraw-Hill Company; 2002. P : 272-303

7. Matic M., Lazetic B., Poljacki M., Duran V. and lvkov-Simic M. Low level laser irradiation and its effectson repair processes in the skin. Med Pregl. 2003; 56(3-4): 137-141

8. Theralase. Therapeutic laser treatment Laser Theory from designers and manufacturers of therapeutic medical laser systems. cited 2018 April 5];Available from:http://wwvv.theralase.com/techn oloqv.php

9. Stadler I., Lanzafame R., Oskoui P., Zhang R., Coleman J. and Whittaker M. Alteration of skintemperature 
during low level laser irradiation at $830 \mathrm{~nm}$ ina mouse model. Photomedicine and Laser Surgery. 2004; 22(3): 227-231

10. Karu T.I. and Kolyakov S.F. Exact action spectra for cellular responses relevant to phototherapy. Photomedicine and Laser Surgery. (2005); 23(4): 355-361

11. Matic M., Lazetic B., Poljacki M., Duran V. and lvkov- Simic M. Low level laser irradiation and its effectson repair processes in the skin. Med Pregl. 2003; 56(3-4): 137-141

12. Olsen J.E., Schimmerling W. and Tobias C.A. Laser action spectrum of reduced excitabilityin nerve cells. Brain Res. 1980; 204: 436-440

13. Dyson M. Primary, secondary and tertiary effects of phototherapy: a review. Mechanisms of Low Level Light Therapy. Mechanisms for LowLight Therapy, edited by Michael R. Hamblin, Ronald W. Waynant, Juanita Anders, Proceedings of SPIE Vol. 6140 SPIE, Bellingham, WA; 2006; 6140, 614005-1 - 614005-12

14. Hawkins, D dan Abrahamse, $H$. Phototherapy - a treatment modality for wound healing and pain relief. African Journal of Biomedical Research. 2007; 10: 99 - 109

15. Smith K. Light and Life: The photobiological basis of the therapeutic use of radiation from lasers. Progress in Laser Therapy: Selected papers from the October 1990 ILTA Congress. Published by Wiley and Sons, Inc. New York and Brisbane; 1991;pp 17

16. Parevri, RS. Pengaruh PNF (Propioceptive Neuromuscular Facilitation) Terhadap Fleksibilitas Otot Member Fitness Centre Pesona
Merapi Di Yogyakarta. 2017; Yogyakarta: UNY

17. Cesário, DF.,Mendes, G., Uchôa, E., dan Veiga, P. 2014. Proprioceptive neuromuscular facilitation and strength training to gain muscle strength in elderly women. Rev. Bras. Geriatr. Gerontol., Rio de Janeiro, 2014; 17(1):67-77

18. Tantawy, S dan Zakaria, H. 2010. The Role of Physical Therapy Intervention in the Management of Diabetic Neuropathic Foot Ulcers. Med. J. Cairo Univ. 2010 September;78(2):103-109, 2010

19. Lorne H., Zinman K.T.N., Mylan N., Bsc S.G. And Bril V. Low-Intensity Laser Therapy for Painful Symptoms of Diabetic Sensorimotor Polyneuropathy. Diabetes Care. 2004; 27 (4)

20. Bulton M. And Marshall J.: He-Ne laser stimulation of human fibroblast proliferation and attachment in vitro. Lasers in Life Sciences. , 1986; 1: 125-134

21. Rinaldi F., Abboetto M., Pontirali A. The diabetic foot general considerations and proposal of a new therapeutic and preventive. Approach. Diabetes Res. Clin. Pract. 1993; 21 (1): 439

22. David G.B., O'kane S. And Dolores T.S. Laser photobiomodulation of wound healing. In. Therapeutic laser therapy and Practice. Eolonbergh, London; 1997; 89: 139,

23. Reddy G.K., Stehno B.L. And Enwemeka G.S.: Laser photo stimulation accelerates wound healing in diabetic rats wound repair and regeneration. 2001; 9 (3): 248- 255

24. Nain Y., JO,. Lanzafame R.J. Effects of photostumulation on wound healing in diabetic mice. In lasers in 
surgery and Medicine. 1991; 20 (1): 56-63

25. Rachkind S., Nissan M., Avram S. And Bartal A. The in-vivo nerve repair to direct low energy laser irradiation. Acta. Neuro. Chir. 1988; 94 (1-2): 74-77

26. Ann M.A., David E.J., James M.F. Evaluation And Prevention Of Diabetic Neuropathy. Am. Fam. Physican. 2005; 71: 2128-2130

27. Sacco I.C.N., Sartor C.D., Gomes A.A., João S.M.A., Cronfli R. Assessment of Motor Sensory Losses In The Foot And Ankle Due To Diabetic Neuropathy. Rev. Bras. Fisioter. Sao. Carlos J. An. 2007; 11 (1): 25-35 